\title{
EVALUATION AND MODELLING OF DISSOLVED OXYGEN AND RE-AERATION RATE IN RIVER PERIYAR, SOUTH INDIA
}

\author{
E. LAKSHMI ${ }^{\mathrm{al}}$ AND G. MADHU ${ }^{\mathrm{b}}$ \\ ${ }^{a b}$ Department of Safety and Chemical Engineering, Cochin University of Science and Technology, Kerala, India
}

\begin{abstract}
Fresh water resources are one of the important resources for protecting and sustaining life on earth. Conservation of these resources has become an important priority for any nation to survive and progress. Rivers around the world are very much polluted and stressed of overuse. Adequate amount of dissolved oxygen is very much important for the growth of aquatic life and overall health of the river. Management of dissolved oxygen in the river requires long term continuous and scientific assessment. Modelling dissolved oxygen in the river and forecasting the future trend will support in understanding the characteristics of the river which further will help in planning management strategies. Periyar river is one of the most polluted rivers in Kerala, South India. River is abused by discharges from industries along the Eloor-Edayar stretch. Statistical evaluation using linear regression analysis and QUAL2K software was used for modelling dissolved oxygen in the river. Dissolved oxygen was predicted for year 2030 using WEAP water quality model. Models were calibrated using 2008 and 2013 data. Re-aeration rate of the river was also evaluated and its change with increasing surface water temperature. From the dissolved oxygen model developed using statistics and QUAL2K, it was found that both models can be used for modelling and prediction of variables in Periyar river. With the rising temperature, the re-aeration rate in the river was found to increase. The results from the paper could be used for planning management strategies for the river with the changing climate scenario.
\end{abstract}

KEYWORDS: Dissolved Oxygen, Dissolved Oxygen Model, QUAL2K, WEAP Water Quality Model, Re-aeration Rate

Rapid increase of industrialization, urbanization, and population explosion in the last few decades have brought about a dramatic increase in the demand for river water, as well as significant deterioration in water quality throughout the world (Chun et al., 2000). The deteriorating water quality affects man, animals, and plant life with far-reaching consequences. Pollution of a river affects its physicochemical characteristics, which gradually and systematically destroy the aquatic community and disturb the delicate food web

Increasing water scarcity together with decreasing quality is forcing developing countries to look into the remedial options of river water quality. The human activity generated contamination from agricultural, municipal, and industrial activities introduces significant amount of organic materials into the rivers and streams, decreasing dissolved oxygen (DO) below a threshold value, which is apparent during low flow periods. The problem of predicting chemical loads in a river system has remained a key issue in the determination of the impact of human activity on aquatic ecosystem environments (Sokolov and Black, 1996). Diverse use of rivers is seriously impaired due to increased pollution. The need for water resource planning and management has also gained attention in recent decades, as degradation of water resources worsened and concern over impact of climate change on water availability increased (Gracia et al., 2008). Therefore, it has become important to assess water quality of rivers and to predict future changes in water quality resulting from the developmental activities in the region. This will help in giving early warning to water quality managers and policy makers about the adverse conditions of the river.

\section{METHODOLOGY}

Periyar River is considered to be the lifeline of central Kerala. Drinking water to the city of Kochi is being supplied from the upstream of the river, that is, from Aluva. The river after flowing through Aluva town, divides into two; one between the Eloor island and Edayar industrial area and the other through Eloor island and Kalamasserry. Edayar accommodates around 500 small and large- scale industries, whereas Eloor has some of the major industries like HIL, Merchem and FACT. Figure 1 gives the geographical location of the sampling points. Sampling locations for water quality analysis is given in table 1 .

The rational use of water resources has become a very important national policy issue in recent years and great efforts have been made to develop environmental management strategies to ensure good water quality and sufficient water supply. In this respect, water quality modeling is increasingly recognized as an effective tool in decision making for water quality management (Zhang et al., 2012). Here, an attempt has been made to develop water quality model for Periyar river using QUAL2K. 


\section{Data Collection and Analysis}

The overall model development process involves creation of a set of data that characterizes the physical aspects, flow, water temperature and quality of the Periyar river. The model was run and the model predictions were compared to a set of measured data describing the river water quality. The model was then calibrated by adjusting model parameters to better fit the model prediction to the measured data. Additional data sets of measured data were used to validate the model to ensure that the model can predict real situations in a reliable manner. The data requirements for the QUAL2K model for simulation include flow, water quality and meteorological data.

Data are required for input to the model, as well as to be used for comparison with model output for calibration and validation purposes. In order to develop QUAL2K model for Periyar river, river stretch from Edamula to Eloor ferry has been divided into 7 reaches. Samples were collected from each reach during April 2007- May 2008. Figure 1 gives the sampling locations with each reach marked along the river. Parameters such as $\mathrm{pH}$, alkalinity, temperature, conductivity, inorganic solids, dissolved oxygen, BOD, COD, organic nitrogen, ammoniacal nitrogen, nitrate-nitrogen, organic phosphorus, and total coliform were used in the analysis of QUAL2K model. Values were evaluated from April 2007 to May 2008. The average values of April-May 2008 and 2013, which is a typical condition of a dry season in the river was used for calibration and validation.

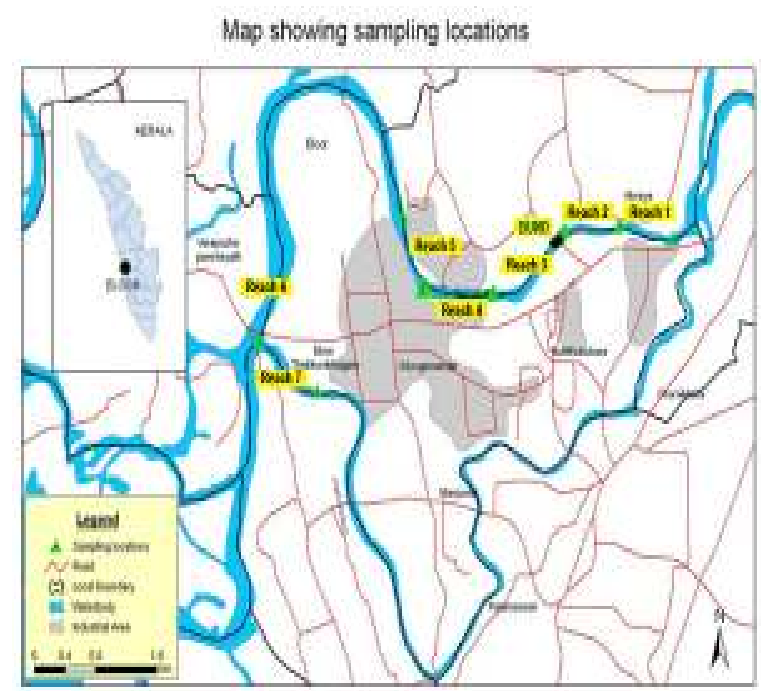

Figure 1: Reach points for QUAL2K model in river Periyar
Table 1: Sampling locations for water quality analysis.

\begin{tabular}{|c|l|}
\hline Sample no. & \multicolumn{1}{c|}{ Sampling points } \\
\hline Reach 1 & Edamula to Pathalam bund North \\
\hline Reach 2 & Pathalam bund North to Bund \\
\hline Reach 3 & Bund to Pathalam bund South \\
\hline Reach 4 & Pathalam bund South to sudchemie \\
\hline Reach 5 & Sudchemie to Pallikadavu \\
\hline Reach 6 & Pallikadavu to Eloor ferry \\
\hline Reach 7 & Kuzhikandam to Eloor ferry \\
\hline
\end{tabular}

Majority of the samples were taken from the river flowing between Eloor and Edayar industrial belt. Sample from the river branch flowing between Eloor Island and Kalamasserry was also taken, which is the discharge point of the Kuzhikandam canal. The parameters affecting the dissolved oxygen were modeled using QUAL2K to evaluate the trend of each parameter in the current scenario for each reach of the river. For QUAL2K modelling, the river is divided into 7 reaches. Reach of the river is decided based on the effluent discharge point to the river. First reach of the river is the upstream of the river with no industries along the river. Second reach has industries along the river and ends near the Pathalam earthen bund. The third reach begins from the Pathalam bund to the discharge point of Sudchemi. The fourth reach starts from the discharge point of Sudchemi to the discharge point of Travancore Cochin Chemicals. The fifth reach is from the Travancore Cochin Chemicals to the Pallikadavu point, which is devoid of any industry. The sixth reach starts from Pallikadavu to Eloor ferry. The seventh reach of the river is from the discharge point of the Kuzhikandam canal to Eloor Ferry. $\mathrm{pH}$, temperature, flow, alkalinity, pathogen, chemical oxygen demand, and Dissolved oxygen were modelled using QUAL 2K. Data collected from the sampling site and secondary data from the literature were used for modelling. Modelling of $\mathrm{pH}$, temperature, flow, alkalinity, pathogen, COD, and DO were done to analyse the trend of these parameters along each reach of the river.

\section{Water Quality Modeling}

Rivers are characterized by a continuous, mostly unidirectional, movement of water. The depth of rivers is usually small (in the order of several $\mathrm{cm}$ to a few meters) and turbulences resulting from shear stress at the river bed prevent vertical stratification (David, 2007). Approaches based on QUAL2K, are highly desirable in estimating river water quality under historical and future scenarios. Some attempts have been made in recent years 
and have been successful in developing and presenting results. Pelletier et al., (2006) confirmed the flexibility and applicability of the QUAL2K model for simulation of river water quality. Zhang et al., (2009) selected the optimal water quality improvement program via simulation of various hypothetical scenarios using the QUAL2K model. So, the QUAL2K model was chosen for the present study due to its popularity and ease of application.

The water quality management strategy involves a series of complex inter-disciplinary decisions based on speculated responses of water quality to changing controls (McIntyre and Wheater, 2004). The complex relationships between waste loads from different sources and the resulting water qualities of the receiving waters are best described with mathematical models (Stolarska et al., 2012). The most widely used mathematical model for conventional pollutant impact evaluation is QUAL2E (Brown and Barnwell, 1987) developed by United States Environmental Protection Agency (USEPA). However, several limitations of the QUAL2E have been reported (Park and Urchin, 1990; Park and Lee, 1996). Pelletier and Chapra (2005) developed a model QUAL2Kw, by modifying QUAL2E, originally developed by Chapra and Pelletier (2003), which is intended to represent a modernized version of QUAL2E.

QUAL2Kw is one-dimensional, steady state stream water quality model and is implemented in the Microsoft windows environment. The model can simulate a number of constituents including temperature, $\mathrm{pH}$, biochemical oxygen demand, sediment oxygen demand, dissolved oxygen, organic nitrogen, ammoniacal nitrogen, nitrite, and nitrate nitrogen, organic phosphorus, inorganic phosphorus, total nitrogen, total phosphorus, phytoplankton and bottom algae. Water quality parameters monitored were : temperature, $\mathrm{pH}$, dissolved oxygen (DO), 5-day biochemical oxygen demand (BOD), Total nitrogen (TN), Total phosphorus (TP), Nitrite+nitrate-nitrogen $\left(\mathrm{NO}_{3}-\mathrm{N}\right)$, Organic nitrogen, ammonia nitrogen $\left(\mathrm{NH}_{4}-\mathrm{N}\right)$, organic phosphorus(TP), inorganic phosphorus, river flow $\left(\mathrm{m}^{3} / \mathrm{s}\right)$, river velocity $(\mathrm{m})$ and river water depth $(\mathrm{m})$. All the monitored parameters were expressed in $\mathrm{mg} / \mathrm{L}$ or $\mu \mathrm{g} / \mathrm{L}$ except $\mathrm{pH}$, temperature $\left({ }^{\circ} \mathrm{C}\right)$, velocity $(\mathrm{m})$, depth $(\mathrm{m})$, and flow $\left(\mathrm{m}^{3} / \mathrm{s}\right)$.

Water quality modelling is widely used in determining the behavior and characteristics of water body (Chapra, 1997). In this study, QUAL2K has been chosen to model the quality of Periyar River. QUAL2K is typically used to assess the environmental impact of multiple pollution discharges along rivers (Chapra and Pelletter, 2003).

Literature values can also be used for establishing reasonable ranges for the parameters. Here, initial parameter set is selected from the analysis result of the sample collected, followed by revisions to improve agreement between model results and measured data (Idris et al., 2016). Final parameters are then chosen to optimize the agreement between the modeled results and the measured data. Ideally, the range of feasible values is determined by measured data. For some parameters, however no observations are available. Then, the feasible range is determined by parameter values employed in similar models or by the judgment of the modeler (Potts, 2014). QUAL2Kw was then run and graphs were developed to show how the different river parameters varied over the course of the river.

River geometry calculated for the water quality modeling using QUAL2K is given below:

Channel slope: At each sample point on the river's course, two ranging poles were held upright on the surface of water which are 10 meters apart. Measure the slope angle from the sample site upstream using a clinometer to the sample site downstream.

Length, km: River lengths were measured using long rope and then length was measured using a tape

Channel width, m: Width was measured using a tape, held across the channel from bank to bank on the water surface.

Bottom width, m: Bottom width is evaluated by taking half the average width across the entire stretch of river.

River velocity: A set distance was measured in the river and then, start and end point are marked. 10 metres was chosen as the distance. Float was put in the water slightly upstream of the start point. Using the stopwatch, time was noted to measure how long it takes the float to move from the start point to the end point. This procedure was repeated atleast five times, in order to measure velocity across the channel. Flow rate was evaluated from the velocity of the river using the formula, $\mathrm{Q}=\mathrm{A} \mathrm{V} ; \mathrm{A}=$ cross sectional area of the river, $\mathrm{V}=$ velocity

QUAL2K simulates a river as a set of interconnected segments, where water quality constituent values are computed for each segment. A segment is defined as a river reach with point and nonpoint inflow sources, as well as withdrawals that drive changes in 
water quality (figure 2). Each segment of the river reach is modeled as having a trapezoidal channel shape.

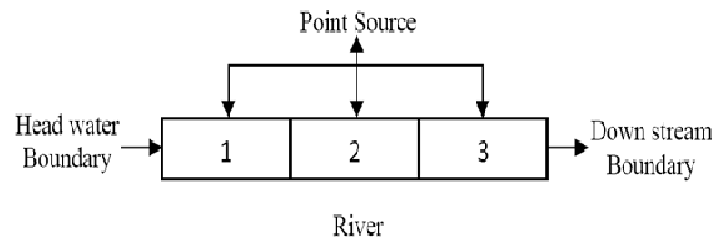

Figure 2: Different reach of the river marked with point source

Data required in modelling (Mc Cutcheon, 1989) are: initial conditions, boundary conditions, data for calibration, and data for validation. Different steps used in any modelling are (Chapra, 1997; Somlyody, 1998, Mc Cuthcheon, 1989):

a. Conceptualization

b. Formulation of Equations

c. Coding/programming

d. Calibration

e. Validation

f. Simulation

g. Sensitivity Analysis

h. Scenario generation

i. Post-audit

\section{Dissolved Oxygen Model}

Following Streeter Phelps equation was used for modelling of dissolved oxygen. The Streeter-Phelps equation, assuming a perfectly mixed stream at steady state is given as:

$\mathrm{D}=\frac{\mathrm{k}_{1} \mathrm{~L}_{\mathrm{a}}}{\mathrm{k}_{2}-\mathrm{k}_{1}}\left(e^{-k_{1} t}-e^{-k_{2} t}\right)+D_{a} e^{-k_{2} t}$

- $\quad \mathrm{D}$ is the saturation deficit, which can be derived from the dissolved oxygen concentration at saturation minus the actual dissolved oxygen concentration $\left(\mathrm{D}=\mathrm{DO}_{\text {sat }}-\mathrm{DO}\right) . \mathrm{D}$ has the dimensions $\frac{g}{\mathrm{~m}^{3}}$

- $\mathrm{k}_{1}$ is the deoxygenation rate, usually in $\mathrm{d}^{-1}$.

- $\mathrm{K}_{2}$ is the reaeration rate, usually in $\mathrm{d}^{-1}$.

- $\mathrm{L}_{\mathrm{a}}$ is the initial oxygen demand of organic matter in the water, also called the ultimate BOD (BOD at time $\mathrm{t}=$ infinity). The unit of $\mathrm{L}_{\mathrm{a}}$ is $\frac{\mathrm{g}}{\mathrm{m}^{3}}$.
- $\mathrm{L}_{\mathrm{t}}$ is the oxygen demand remaining at time $\mathrm{t}, \mathrm{L}_{\mathrm{t}}=$ $L_{a} e^{-k_{1} t}$

- $\mathrm{D}_{\mathrm{a}}$ is the initial oxygen deficit $\left[\frac{g}{m^{3}}\right]$.

- $\quad \mathrm{T}$ is the elapsed time, usually [d].

$\mathrm{k}_{1}$ lies typically within the range $0.05-0.5 \mathrm{~d}^{-1}$ and $\mathrm{k}_{2}$ lies typically within the range $0.4-1.5 \mathrm{~d}^{-1}$

\section{Statistical Error Analysis}

The goodness of fit was tested by percent bias (PBIAS) between the difference of model predictions and observed data for water quality constituents. These statistical error parameters are commonly used for calibration and validation of the models (Najafzadeh et al., 2013)

PBIAS $=(\Sigma(\mathrm{O}-\mathrm{P}) / \Sigma(\mathrm{O}) * 100 ; \mathrm{O}=$ observed data; $\mathrm{P}=$ predicted data.

\section{Reaeration Rate in the River}

Re aeration rate in the river is evaluated using the Connor-Dobbins formula

$\mathrm{K}_{\mathrm{a}}=3.93 \frac{U^{0.5}}{H^{1.5}}$

Where $U=$ Velocity, $\mathrm{m}^{2} / \mathrm{s} ; \mathrm{H}=$ Depth, $\mathrm{m}$

Dissolved oxygen saturation was evaluated using the formula,

$\mathrm{DO}_{\mathrm{s}}=0.0035 \mathrm{~T}^{2}-0.3369 \mathrm{~T}+14.407$ (Chapra and canale, 1998).

Dissolved oxygen deficit is evaluated using,

$\mathrm{D} \mathrm{O}_{\text {defecit }}=\mathrm{D} \mathrm{O}_{\text {saturation }}-\mathrm{DO}$

Distance to achieve Critical Point in a reach is the product of the speed of the stream, the travel time, and discharge to the reach

$\mathrm{x}, \mathrm{Km}=(\mathrm{v})(\mathrm{t})($ discharge for each reach)

Re-aeration rate for different temperature scenarios are analyzed using a formula. The re-aeration coefficient as a function of temperature has been given by

$K_{T}=K_{T}^{20} \theta(T-20)$

Where $\mathrm{T}$ is in degrees Celsius and $\theta$ depends on the mixing condition of the water body. Values of $\theta$ have been given in the range from 1.005 to 1.030 , with the value of 1.024 normally used in practice (Thomann and Mueller, 1987). 


\section{RESULTS AND DISCUSSION}

\section{Regression Analysis of Water Quality Variables with Dissolved Oxygen}

Linear regression model was applied to significantly correlated water quality parameters with dissolved oxygen. An equation was derived with, dissolved oxygen as dependent variable and parameters BOD, organic nitrogen, ammoniacal nitrogen, organic phosphorus, alkalinity and $\mathrm{pH}$ as independent variable.
Table 2: Regression result of water quality variables with dissolved oxygen

\begin{tabular}{|c|c|}
\hline R Square & 1.00 \\
\hline Adjusted R Square & 1.00 \\
\hline Standard Error & 0.004 \\
\hline Observations & 72 \\
\hline
\end{tabular}

Table 3: Coefficients of regression analysis between water quality variables and dissolved oxygen

\begin{tabular}{|c|c|c|c|}
\hline \multirow{2}{*}{ Model } & \multicolumn{2}{|c|}{ Unstandardized Coefficients } & Standardized Coefficients \\
\cline { 2 - 4 } & $\mathrm{B}$ & Std. Error & Beta \\
\hline (Constant) & -0.297 & .000 & -0.158 \\
\hline BOD & -0.470 & .000 & -0.248 \\
\hline Org.N & -2.028 & .000 & 0.076 \\
\hline Ammoniacal nitrogen & 0.827 & .000 & 0.066 \\
\hline Organic phosphorus & 0.331 & .000 & -0.645 \\
\hline alkalinity & -0.163 & .000 & 0.433 \\
\hline pH & 1.832 & .000 & \\
\hline
\end{tabular}

As this is a statistical calculation, deviations and errors are likely to be present. Percent bias (PBIAS) error analysis of the linear regression shows an error of $0.004 \%$. However, in spite of an error which is very low, this method is very useful, because, otherwise analysis of each parameter is very costly and time-consuming. Since dissolved oxygen shows high correlation with BOD, alkalinity, $\mathrm{pH}$, Organic phosphorus, ammoniacal nitrogen, organic nitrogen, and regression equation relating dissolved oxygen with parameters have been formulated (Table 3). given below:

Regression equation derived from the analysis is

DO mg/l = -0.297 - 0.470BOD - 2.028Organic nitrogen

+0.827 Ammoniacal nitrogen+

0.331 Organic phosphorus -0.163 Alkalinity $+1.83 \mathrm{pH}---$ --- (8)

This method thus gives a superior alternative.

This approach is useful in detecting changes in water quality within the system and can be used to predict or forecast values of the dependent variable dissolved oxygen.

\section{QUAL2K Model Geometry}

River channel is divided into 7 reaches and length was calculated for each reach. Total length of the river under consideration is $17.4 \mathrm{~km}$ (Edamula to Eloor ferry). Length, flow rate, elevation, channel slope, Manning's roughness coefficient, bottom width, side slope, surface width, and velocity of each reach is given in the table 3. As a calibration factor, Manning's roughness parameter ' $n$ ' was chosen to be 0.045 (Chow et al., 1988; Chapra et al., 2006). Value for Manning ' $n$ ' is given from the manning roughness coefficient for various rivers which are clean, winding open channels (Chow, 1959). Elevation in the river was not evaluated, so taken as zero. Channel slope was analyzed to be 0.002 for almost all of the reach using clinometers. Cross-section profiles of the river are considered to be in the form of a manning trapezoid with a bottom width and channel slope. So, bottom width is evaluated to be $84 \mathrm{~m}$. Surface width in the river range from 110 to $122 \mathrm{~m}$ and side slope of the river is taken as zero. Average value of pre-mosoon and monsoon season is taken for surface width and depth of the river. Flow rate increases downstream with each reach. It is higher for reach 6 and 7. 
Table 4: River geometry for model development

\begin{tabular}{|c|c|c|c|c|c|c|c|c|c|c|}
\hline \multirow[b]{2}{*}{ Reach } & \multirow{2}{*}{$\begin{array}{c}\text { Reach } \\
\text { length } \\
(\mathbf{k m}) \\
\end{array}$} & \multirow{2}{*}{$\begin{array}{c}\text { Flow } \\
\text { rate } \\
\left(\mathrm{m}^{3} / \mathbf{s}\right) \\
\end{array}$} & \multirow[b]{2}{*}{$\begin{array}{l}\text { Elevation } \\
\text { (m) }\end{array}$} & \multicolumn{4}{|c|}{ Manning Formula } & \multirow{2}{*}{$\begin{array}{c}\text { Surface } \\
\text { width } \\
\text { (m) }\end{array}$} & \multirow{2}{*}{$\begin{array}{c}\text { Velocity } \\
\left(\mathrm{m}^{2} / \mathrm{s}\right)\end{array}$} & \multirow[b]{2}{*}{$\begin{array}{c}\text { Depth } \\
\text { (m) }\end{array}$} \\
\hline & & & & $\begin{array}{c}\text { Channel } \\
\text { slope }\end{array}$ & $\begin{array}{c}\text { Manning } \\
\text { (n) }\end{array}$ & $\begin{array}{c}\text { Bottom } \\
\text { width (m) }\end{array}$ & $\begin{array}{c}\text { Side } \\
\text { slope }\end{array}$ & & & \\
\hline 1 & 1.0 & 64 & 0 & 0.002 & 0.045 & 84 & 0 & 110 & 0.16 & 3.8 \\
\hline 2 & 1.5 & 68.4 & 0 & 0.002 & 0.045 & 84 & 0 & 112 & 0.18 & 3.6 \\
\hline 3 & 2.0 & 68.4 & 0 & 0.002 & 0.045 & 84 & 0 & 114 & 0.19 & 3.2 \\
\hline 4 & 2.6 & 70.2 & 0 & 0.002 & 0.045 & 84 & 0 & 116 & 0.20 & 3.0 \\
\hline 5 & 2.8 & 70.8 & 0 & 0.002 & 0.045 & 84 & 0 & 118 & 0.21 & 2.8 \\
\hline 6 & 4.0 & 71.2 & 0 & 0.002 & 0.045 & 84 & 0 & 120 & 0.23 & 2.6 \\
\hline 7 & 3.5 & 72 & 0 & 0.002 & 0.045 & 84 & 0 & 122 & 0.27 & 2.2 \\
\hline
\end{tabular}

\section{Meteorological Data for QUAL2K Model}

Meteorological data are essential part of water quality model. These data provide the basis for coefficients applied in model equations affecting water quality. Weather inputs such as air temperature, dew point, and wind speed are used in calculations for heat transfer, evaporation, and surface re-aeration. Secondary data of monthly air temperature, wind speed and dew point (Table 5) are collected from Indian Meteorological Department, Trivandrum for a period of one year and one month (April 2007- May 2008).

Table 5: Meteorological data for QUAL2K model

\begin{tabular}{|c|c|c|c|c|c|c|c|c|c|c|c|c|c|c|}
\hline & $\begin{array}{c}\text { Apr } \\
\mathbf{0 7}\end{array}$ & $\begin{array}{c}\text { May } \\
\mathbf{0 7}\end{array}$ & $\begin{array}{c}\text { June } \\
\mathbf{0 7}\end{array}$ & $\begin{array}{c}\text { July } \\
\mathbf{0 7}\end{array}$ & $\begin{array}{c}\text { Aug } \\
\mathbf{0 7}\end{array}$ & $\begin{array}{c}\text { Sep } \\
\mathbf{0 7}\end{array}$ & $\begin{array}{c}\text { Oct } \\
\mathbf{0 7}\end{array}$ & $\begin{array}{c}\text { Nov } \\
\mathbf{0 7}\end{array}$ & $\begin{array}{c}\text { Dec } \\
\mathbf{0 7}\end{array}$ & $\begin{array}{c}\text { Jan } \\
\mathbf{0 8}\end{array}$ & $\begin{array}{c}\text { Feb } \\
\mathbf{0 8}\end{array}$ & $\begin{array}{c}\text { Mar } \\
\mathbf{0 8}\end{array}$ & $\begin{array}{c}\text { Apr } \\
\mathbf{0 8}\end{array}$ & $\begin{array}{c}\text { May } \\
\mathbf{0 8}\end{array}$ \\
\hline Wind speed & 12.5 & 13 & 11.5 & 9.5 & 11 & 11 & 8.5 & 9.5 & 9.5 & 11.5 & 14.5 & 8.5 & 11 & 12 \\
\hline Dew point & 24.7 & 24.5 & 24.2 & 24.1 & 23.8 & 24.1 & 23.7 & 23 & 21.1 & 21 & 22.7 & 23 & 24.9 & 24.6 \\
\hline $\begin{array}{c}\text { Air } \\
\text { temperature }\end{array}$ & 30 & 29.4 & 27.3 & 26.3 & 26.5 & 26.3 & 27.1 & 27.6 & 27.2 & 26.9 & 28.1 & 27.7 & 29.1 & 29.1 \\
\hline
\end{tabular}

\section{Model Development of Dissolved Oxygen Using QUAL2K}

Compared to prehistoric times, the level of oxygen in the earth's atmosphere has declined by over a third and in polluted cities the decline may be more than $50 \%$. (UNEP, 2004). At these levels it is difficult for people to get sufficient oxygen to maintain bodily health: it takes proper intake of oxygen to keep body cells and organs, and the entire immune system, functioning at full efficiency (Laszlo, 2001). Gradually, decrease in atmospheric oxygen affects the re-aeration rate of a river, further reducing the dissolved oxygen in the river.

Dissolved Oxygen in rivers is fluctuating in a very alarming rate. There has been incidence of fish death and discoloration in the river. Modelling of dissolved oxygen in the river will help managers and policy makers to plan different strategies for conservation and management of the river.

\section{Dissolved Oxygen Model of Periyar River}

The overall model development process involves creation of a set of data that characterizes the physical aspects of the Periyar river and describes the flow and quality at the upstream end of the river. The model was run and the model predictions were compared to a set of measured data describing the river water quality. The model was then calibrated by adjusting model parameters to better fit the model prediction to the measured data. The data requirements for the QUAL2K model for one simulation involve flow, water quality, and meteorological data. Data are required for input to the model, as well as data to be used for comparison with model output for calibration purposes. Model was prepared with monthly dissolved oxygen data of Periyar river from April 2007-May 2008. The data was calibrated with dissolved oxygen values of April-May 2008 \& 2013. Average of April-May 2008 \& 2013 data was used for reasons such as low flow of the river, high air and water temperature, and high pollutant concentration during the sampling period.

\section{Dissolved Oxygen Calibration}

Once the model geometry in terms of width, slope and the appropriate time of travel was defined, water quality modelling was done and further concentrated on calibration process. The adjustments in the hydrodynamic calibration improved the dissolved oxygen results compared to the value obtained in the first 
run of the model, requiring only minor adjustments of the water quality rates in order to achieve a satisfactory dissolved oxygen calibration.

\section{QUAL 2K Water Column Rates}

QUAL2K model was calibrated by adjusting coefficients and rates in order to reproduce time of travel and dissolved oxygen in the longitudinal profile. Literature values were used as a first approximation and their value were fine tuned through the process of calibration.
Dissolved oxygen data from April 2007 to March 2008 (figure 6) was taken as model data with 2013 April -May average as calibration (observed) data. From the figure 3 , it is clear that the model developed is very much in agreement with calibrated DO value of 2013 (April-May average). Overall, the model is considered reasonably calibrated because the model simulated pollutants of interest is within the range shown by the observed data. The model reproduced the general water quality trends reasonably well throughout the system.

Table 6: Model data of dissolved oxygen data for Periyar river

\begin{tabular}{|c|c|c|c|}
\hline Reach & Model, (mg/l) & Observed 2008 data,(mg/l) & Observed 2013 data, (mg/l) \\
\hline 1 & 5.6 & 5.6 & 5.65 \\
\hline 2 & 5.5 & 5.5 & 5.6 \\
\hline 3 & 5.7 & 5.7 & 5.8 \\
\hline 4 & 5 & 5 & 5.2 \\
\hline 5 & 5.9 & 5.9 & 6 \\
\hline 6 & 3.8 & 3.9 & 4 \\
\hline 7 & 2 & 2.1 & 2 \\
\hline
\end{tabular}

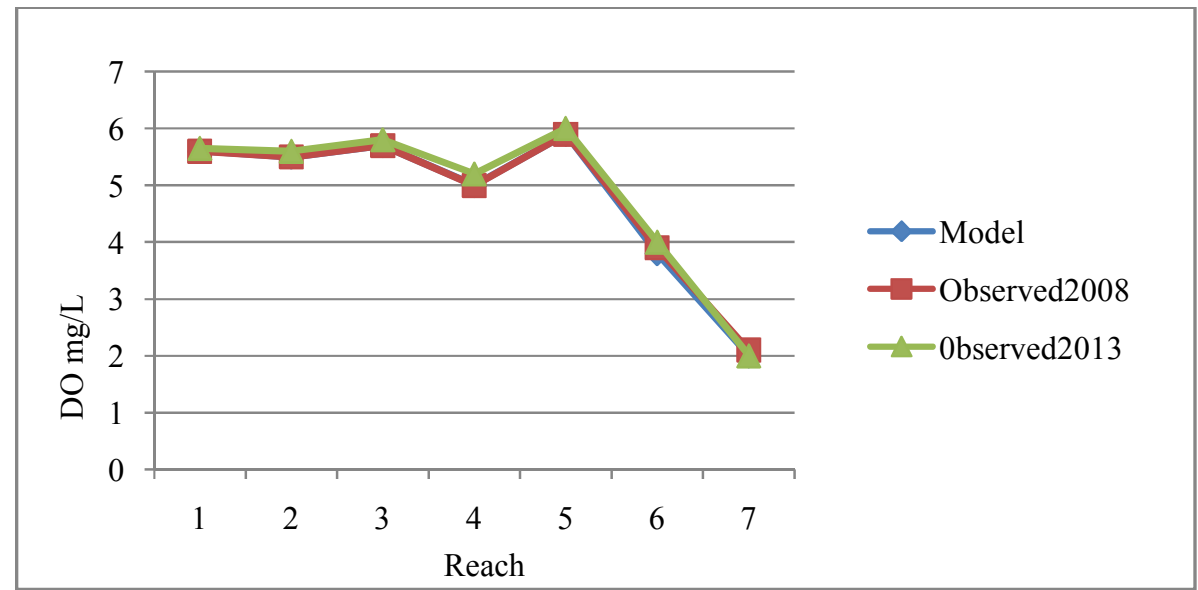

Figure 3: Calibration of modeled dissolved oxygen values of Periyar river with observed values

From the dissolved oxygen model developed with QUAL2K, it is observed that the dissolved oxygen in the river reduces drastically towards downstream. After reach 4 from the upstream of the river, the dissolved oxygen reduce below $5 \mathrm{mg} / 1$ and then regains to $6 \mathrm{mg} / 1$ in the reach 5 further to reduce very much below $4 \mathrm{mg} / 1$ towards downstream (reach 6 and reach 7). Presence of dissolved oxygen below $4 \mathrm{mg} / 1$ is very much unsuitable for the survival of aquatic life.

The goodness of fit was tested by percent bias (PBIAS) between the observed and predicted data. To test the ability of the calibrated model to predict water quality conditions, the model was run to estimate water quality values observed without changing the calibrated parameters. The error analysis shows that there is an error of $2.47 \%$ for dissolved oxygen model. Generally, the model calibration results were in modest agreement with the measured data. The PBIAS error analysis between the simulated and observed values indicates that the model can be calibrated in one condition and still be rather valid in another. Dissolved oxygen model developed can be used for further studies of Periyar river and other similar ecosystem. 


\section{Forecasting of Dissolved Oxygen in Periyar River}

QUAL2K model data developed for dissolved oxygen was linked to WEAP water quality model to predict dissolved oxygen for year 2030. Forecasting of dissolved oxygen is done with the 2007-2008 as current accounts and 2009-2030 as reference data through time series forecasting of WEAP water quality model.

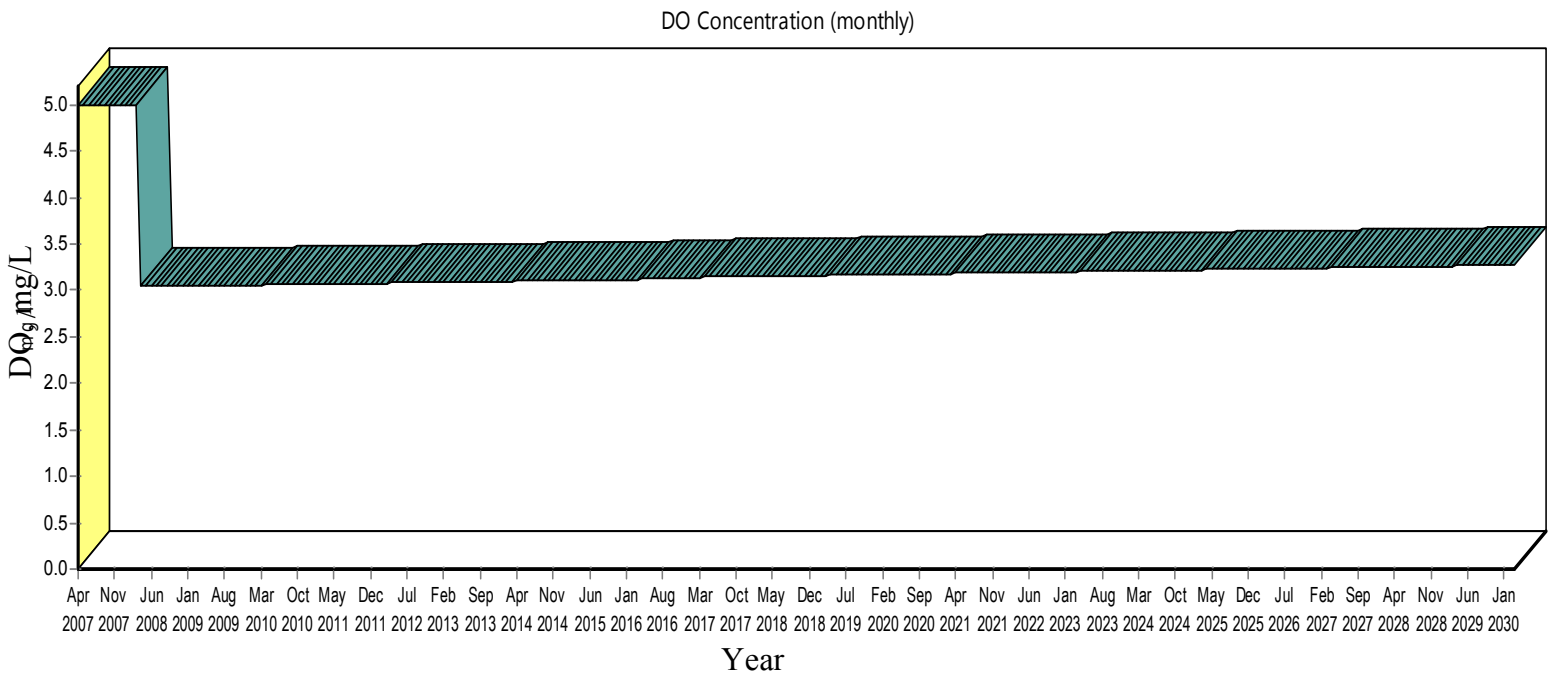

Figure 4: Forecasting dissolved oxygen in Periyar river by year 2030

From the figure 4 , it is observed that by 2030 dissolved oxygen of the river would be $3.7 \mathrm{mg}$ oxygen $/ 1$. Low dissolved oxygen affects the health of the river. It affects aquatic organisms, reduces degradation of organic and inorganic waste. Dissolved oxygen can affect the solubility and availability of nutrients, which can be released from sediments under conditions of low dissolved oxygen (Li et al., 2008).

Comparison of Error Analysis between Models Developed Using Linear Regression Analysis and QUAL2K for Dissolved Oxygen

A comparison of error developed during linear regression analysis and QUAL2K model for dissolved oxygen was done. Linear regression analysis done with dissolved oxygen as dependent variable and parameters $\mathrm{BOD}$, organic nitrogen, ammoniacal nitrogen, organic phosphorus, alkalinity and $\mathrm{pH}$ as independent variable gives an error of $0.004 \%$. Dissolved oxygen model using QUAL2K presents an error of $2.47 \%$. Even though linear regression analysis shows lesser error compared to QUAL2K analysis, QUAL2K model can also be used for modeling studies of Periyar river and similar ecosystems.

\section{Re-aeration in Periyar River}

Re-aeration of a river is proportional to the oxygen deficit. The re-aeration rate increases as the oxygen deficit increases and later, the re-aeration rate becomes equal to the rate of oxygen consumption (Wilcock, 1988). The critical point, is the point in the river beyond which, the re-aeration rate exceeds the rate of oxygen consumption, resulting in gradual decline in the oxygen deficit from the discharge point of each reach of the river (Kulkarni, 2017).

Table 7: Re-aeration rate in the Periyar river

\begin{tabular}{|c|c|c|c|c|c|}
\hline Reach & $\begin{array}{c}\text { DO saturation, } \\
(\mathbf{m g} / \mathbf{l})\end{array}$ & $\begin{array}{c}\text { Re-aeration } \\
\text { rate (\%) }\end{array}$ & $\begin{array}{c}\text { Dissolved oxygen, } \\
(\mathbf{m g} / \mathbf{l})\end{array}$ & $\begin{array}{c}\text { DO deficit, } \\
(\mathbf{m g} / \mathbf{l})\end{array}$ & $\begin{array}{c}\text { Distance of } \\
\text { critical point, }(\mathbf{m})\end{array}$ \\
\hline 1 & 7.507 & 0.229 & 6.97 & 0.537 & 8210.3 \\
\hline 2 & 7.47 & 0.263 & 6.51 & 0.96 & 9768 \\
\hline 3 & 7.45 & 0.295 & 6.62 & 0.83 & 10544 \\
\hline 4 & 7.44 & 0.332 & 6.40 & 1.04 & 7689.90 \\
\hline 5 & 7.47 & 0.377 & 6.72 & 0.75 & 8677.2 \\
\hline 6 & 7.42 & 0.440 & 3.78 & 3.64 & 9295.4 \\
\hline 7 & 7.32 & 0.578 & 3.27 & 4.1 & 8305.2 \\
\hline
\end{tabular}


From the re aeration rate analysis of the river, Reach 3 requires maximum distance $(10 \mathrm{~km})$ from the point of discharge and the reach 6 , requires $9 \mathrm{~km}$ from the point of discharge to achieve the critical point. Each reach require to travel about $7-10 \mathrm{~km}$ to achieve the critical point. This can be attributed to the discharge of effluent from the industries situated in each reach.

Re-aeration rate of Periyar river is analyzed for different hypothetical temperature scenarios. From the analysis (Table 8), it was observed that as the surface temperature of the river increases, there is a gradation in the re-aeration rate of the river. As the surface temperature of the river increases, the capacity of the water to hold dissolved oxygen decreases. This increases the re-aeration rate that is, the diffusion of oxygen from the atmosphere into the water and by the turbulent mixing of water and air. Result is given in the table 8 below.

Table 8: Re-aeration rate for each reach with different temperature scenarios

\begin{tabular}{|c|c|c|c|c|c|c|}
\hline \multicolumn{2}{|c|}{$\begin{array}{c}\text { Scenarios } \\
\text { (Increase in temperature) }\end{array}$} & $+0.24^{\circ} \mathrm{C}$ & $+0.48^{\circ} \mathrm{C}$ & $+0.72^{\circ} \mathrm{C}$ & $+0.96^{\circ} \mathrm{C}$ & $+1.2^{\circ} \mathrm{C}$ \\
\hline \multirow{2}{*}{ Reach 1} & Temp & 29.7 & 30.03 & 30.27 & 30.51 & 30.75 \\
\hline & Reaeration rate & 0.288 & 0.29 & 0.291 & 0.293 & 0.295 \\
\hline \multirow{2}{*}{ Reach 2} & Temp & 30.1 & 30.25 & 30.49 & 30.73 & 30.97 \\
\hline & Reaeration rate & 0.33 & 0.335 & 0.337 & 0.339 & 0.341 \\
\hline \multirow{2}{*}{ Reach 3} & Temp & 30.2 & 30.46 & 30.7 & 30.98 & 31.18 \\
\hline & Reaeration rate & 0.37 & 0.378 & 0.38 & 0.382 & 0.384 \\
\hline \multirow{2}{*}{ Reach 4} & Temp & 30.26 & 30.5 & 30.74 & 30.98 & 31.22 \\
\hline & Reaeration rate & 0.423 & 0.425 & 0.428 & 0.43 & 0.433 \\
\hline \multirow{2}{*}{ Reach 5} & Temp & 30.08 & 30.32 & 30.56 & 30.8 & 31.04 \\
\hline & Reaeration rate & 0.478 & 0.481 & 0.484 & 0.487 & 0.489 \\
\hline \multirow{2}{*}{ Reach 6} & Temp & 30.4 & 30.64 & 30.88 & 31.12 & 31.36 \\
\hline & Reaeration rate & 0.563 & 0.566 & 0.569 & 0.572 & 0.576 \\
\hline \multirow{2}{*}{ Reach 7} & Temp & 30.84 & 31.08 & 31.32 & 31.56 & 31.8 \\
\hline & Reaeration rate & 0.747 & 0.75 & 0.756 & 0.760 & 0.764 \\
\hline
\end{tabular}

From the analysis, we can observe that there is an increase of $1-2 \%$ in re-aeration rate for an increase of temperature from $+1.2^{0} \mathrm{C}$ to $2.4^{0} \mathrm{C}$ from the current scenario. With increase in temperature there is reduction in dissolution of dissolved oxygen in the river, which causes oxygen deficiency in the river. Oxygen deficiency affects the degradation of effluents discharged to the river, further degrading the oxygen in the river. River Periyar receives continuous flushing of effluent discharge from industries which fluctuates the concentration of dissolved oxygen. Reduction in dissolution of oxygen with increase in surface water temperature will further reduce dissolved oxygen in the river. According to the scenario analyzed, with each increase in surface water temperature, the re-aeration rate of the river is observed to increase.

\section{CONCLUSION}

Linear regression analysis done to dependent dissolved oxygen and independent $\mathrm{pH}$, alkalinity, organic nitrogen, ammoniacal nitrogen, organic phosphorus variables presents an equation with an error of $0.004 \%$
(PBIAS error analysis) which can be used for predicting dissolved oxygen in the river.

Dissolved oxygen model developed with QUAL2K is found to be in agreement with the calibrated and observed data. Dissolved oxygen is found to reduce below $4 \mathrm{mg} / 1$ towards downstream, which is detrimental for the survival of aquatic organisms. In this scenario analyzing the self purifying capacity or capability to regain dissolved oxygen in the river as the river flows is very much important. So, Evaluation of re-aeration rate, dissolved oxygen saturation, dissolved oxygen deficit and the distance of critical point was done to the Periyar river.

QUAL2K clearly has potential for assessing water quality along the river and could be implemented as a valuable tool to inform Periyar river management strategies. From the study, it appears that DO should be manipulated using well-defined management strategies to keep DO concentrations above minimum allowable levels. Decision makers and river basin managers associated with the Periyar river can use the findings of this paper as a decision support tool. Since QUAL2K 


\section{LAKSHMI AND MADHU: EVALUATION AND MODELLING OF DISSOLVED OXYGEN AND RE-AERATION RATE IN ...}

model is purely based on existing data, the methodology may be used for other rivers, based on the availability of data. The QUAL2K model could be used to simulate the amount of DO required and the potential impacts of such management on other water quality factors along the entire river. As such, the implementation of QUAL2K with regard to optimization techniques and accuracy assessments under various conditions warrants further consideration.

Re-aeration rate of each reach in the river was evaluated. Re-aeration rate ranged between 0.229 and $0.578 \%$ in the river. Critical point analysis of each reach reveals that the reach 3 requires the maximum distance, that is, $10 \mathrm{~km}$ and reach 6 requires $9 \mathrm{~km}$ from the point of discharge to get fully decomposed. Effluent Discharge from each reach in the Periyar river need to travel $8-10$ $\mathrm{km}$ from the point of discharge to attain the critical point. Re-aeration rate of the river is found to increase by $1-2 \%$ for an increase of $1.2^{\circ} \mathrm{C}$ to $2.4^{\circ} \mathrm{C}$ water temperature in the river. With increase in water temperature due to climate change and discharge of effluents from industries the reaeration rate in the river is bound to increase.

It is observed that models developed using linear regression and QUAL2K can be used for studying and prediction of Periyar river and similar other river ecosystems. Periyar river water quality was represented for the first time using one-dimensional QUAL2K. We could develop good model for dissolved oxygen and calibrate it well with the model.

\section{ACKNOWLEDGEMENT}

On behalf of all authors Dr. E. Lakshmi and Dr. G. Madhu, the corresponding author states that there is no conflict of interest.

\section{REFERENCES}

Arnell et al., 2004. Climate and socio economic scenarios for global scale climate change impacts assessmenrs characterizing the SRES storylines. Journal of global environmental change.14:3-20.

AMEC Earth \& Environmental and ERO Resources Corporation, 2008. Stream water quality modeling and methods report. Windy gap firming project, Colorado.

APHA (1998) Standard methods for the examination of water and wastewater. United book press. Baltimore. Maryland, USA.
APHA, 2012. Standard methods for the examination of water and waste water. $22^{\text {nd }}$ edition.

Benyahya L., 2007. A review of statistical water temperature models. Canadian water resources journal. Canadian water resources association, 32.3:179-192.

Brown L.C. and Barnwell T.O., 1987. The Enhanced Stream Water Quality Models QUAL2E and QUAL2E-UNCAS: Documentation and user manual. USEPA, environmental research laboratory. Athens, GA.

Bruce W., Webb and Franz N., 2007. Long-term changes in river temperature and the influence of climatic and hydrological factors. Hydrological Sciences Journal, 52.1:74-85.

California Regional Water Quality Control Board, 2010. Total maximum daily load and implementation plan for dissolved oxygen in the New river at the international boundary. Colorado River Basin Region. Palm Desert, California.

Caissie D., El-jabi N. and Satish M.G., 2001. Modeling of maximum daily water temperature in a small stream using air temperatures. Journal of hydrology, 251:14-28.

Chapra S., Pelletier G. and Tao H., 2006. QUAL2K: A Modeling framework for simulating river and stream water quality, version 2.04. Documentation and users manual, civil and environmental engineering department. Tufts University. Medford, MA.

Chapra S., 1997. Surface water quality modelling. New York. McGraw-Hill.

Chapra S.C. and Pelletier G.J., 2003. QUAL2K: A Modeling Framework for Simulating River and Stream Water Quality (Beta Version): Documentation and Users Manual. Civil and environmental engineering department. Tufts University.

Chun, 2000. Water quality studies of Shodganga. Chapter 2. $\mathrm{PhD}$ thesis.

Chapra S.C., 1997. Surface water quality modeling. McGraw-Hill: New York.

Chapra S.C. and Canale R.P., 1998. Numerical methods for engineers with programming and scientific applications. New York:Mc Graw- Hill. 839. 


\section{LAKSHMI AND MADHU: EVALUATION AND MODELLING OF DISSOLVED OXYGEN AND RE-AERATION RATE IN ...}

Chong-Yu X., 2000. Modeling the effects of climate change on water resources in Central Sweden. Water resources management, 14:177-189.

Chow V.T., 1964. Handbook of Applied Hydrology. New York: McGraw Hill.

Chow et al., 1988. Applied Hydrology. McGraw Hill.

Climate Change, Working Group 1 (2007) The Physical Science Basis.

Cole T.M. and Wells S.A., 2003. CE-QUAL-W2: A twodimensional, laterally averaged, hydrodynamic and water quality model. Version 3.2. Instruction report EL-03-1. US army engineering and research development center, Vicksburg.

Cox B.A. and Whitehead P.G., 2009. Impacts of climate change scenarios on dissolved oxygen in the river Thames, UK. Hydrology Research, 4(2-3): $138-152$.

David K., 2007. A Water Quality Model for Shallow River-Lake Systems and its application in river basin management. University of Potsdam, Germany for the degree of Doctor of natural sciences

Deborah P. and Giuseppe G., 2010. Modeling of Po river water quality in Torino, Italy. Water resource management, 24: 2937-2958.

Eatherall A. et al., 1998. Modeling in-stream water quality in LOIS. Science total environment. 210\&211: 499-517.

Fan C., Ko C.H. and Wang W.S., 2012. An innovative modeling approach using QUAL2K and HECRAS integration to assess the impact of tidal effect on river water quality simulation. Journal of Environment and management, 90: 18241832.

Fang X., Zhang J., Chen Y. and Xu X., 2008. QUAL2K model used in the water quality assessment of Qiantang river, China. Journal of water environment resource, 80: 2125-2133.

Gardner, 2008. Stream water quality modeling and methods report - a report on QUAL2K-Windy Gap Firming Project.

Gardner, 2007. A QUAL2K water quality analysis of the Rio Blanco watershed near Jalisco, Mexico. A report submitted to Dr. Jim Nelson - Water Resources Engineering. Department of Civil and
Environmental Engineering.Brigham Young University.

Glaser D. and Bridges T., 2007. Separating the wheat from the chaff: The effective use of mathematical models as decision tools. Integrated environment assessment and management, 3: 442-449.

Gracia et al., 2008. Water for forests and people of Mediterranean region- a challenging balance. European Forest Institute. European Union.

Husband H.A. Scherer, 2010. Dissolved oxygen TMDL for the Souris river in Renville and Burke counties, North Dakota. North Dakota Department of health. Division of water quality.

Idris, 2016. Assessment of Surface Water Quality Using Qual2k Software: A Case Study of River Yamuna, India. European Journal of Advances in Engineering and Technology, 3(7): 16-23 ISSN: 2394 - 658X 16.

James A., 1993. An Introduction to water quality modelling. $2^{\text {nd }}$ edition. John Wiley \& Sons Ltd, New York.

Jayapalan et al., 1976. Some aspects of the physiochemical and biological variations in Periyar water due to the effluent discharge from FACT. Bulletin from department of fisheries. Kerala, 1: 47-59.

Joseph M.L., 2000. Status report on Periyar river. The declining trend of biodiversity.

Joseph K.J. et al., 1984. Studies on phytoplankton in polluted waters. Journal of marine science, 32: 54-58.

Kulkarni S.J., 2017. Analysis of Dissolved Oxygen Deficit in a Flowing Stream. International Journal of Thermal \& Environmental Engineering, 15(2): 97-102

Langan S.J., Johnston L., Donaghy M.J., Youngson A.F., Hay D.W. and Soulsby C., 2001. Variation in river water temperatures in an upland stream over a 30 year period. Journal of the Science of the total environment, 265: 195-207.

Langbein W.B. and Durum W.H., 1967. The aeration capacity of streams. 
Laszlo E. and Clarke A.C., 2001. Navigating the transformation to a sustainable world. BerrettKoehler Publisher.

Liebscher H.J., 1993. Hydrology for the water management of large river basins. Hydrological sciences journal, 38(1): 1-13.

Li B., Zhang K., Zhong B.C. and Wang D.Z., 2008. An experimental study on release of pollutants from sediment under hydrodynamic conditions. Journal of Hydrodynamics A, 23(2): 126-133.

Local Area Environment Committee for Eloor- Edayar area (LAEC), 2004. Constituted as per the order no: P Pollution Control Board/HO/Hazardous Waste Management/Supreme Court Monitoring Committee.

Loucks D.P., 2008. Water resources systems planning and management-An introduction to methods, models and applications. Studies and reports on hydrology. UNESCO.

Luis A., Camacho R.A. and Gonzalez, 2008. Calibration and predictive ability analysis of longitudinal solute transport models in mountain streams. Environment Fluid Mechanics, 8: 597-604.

Mackey A.P. and Berrie A.D., 1991. The prediction of water temperatures in chalk streams from air temperatures. Hydrobiologia, 210: 183-189.

Mahdieh E. et al., 2012. Validation of MIKE 11 Model Simulated Data for Biochemical and Chemical Oxygen Demand Transport . American Journal of Applied Sciences, 9(3): 382-387.

Mahamah D.S., 1998. Simplifying assumptions in water quality modeling. Ecological Model, 109: 295300 .

Martin J. and McCutcheon, 1999. Hydrodynamics and transport for water quality modelling. CRC Press, New York.

Marce R. and Armengol J., 2008. Modeling river water temperature using deterministic, empirical and hybrid formulations in a Mediterranean stream. Hydrological Processes, 22: 3418-3430.

Mc McCarthy J., Canziani O.F., Leary N.A., Dokken D.J. and White K.S. (eds), 2001. IPCC Climate change: Vulnerability, impacts and adaptation, Contribution of Working Group ii to the third assessment report of the Intergovernmental
Panel on climate change. In: Cambridge University Press. Cambridge. UK. 1032.

McIntyre N.R. Wheate, et al., 2004. Assessment of rainfall-runoff model structures for regionalisation purposes. Hydrology: science and practice for the $21^{\text {st }}$ century, pp. 302-308.

McCutcheon S.C., 1989. Water quality modelling. Vol. 1. Boca Raton, Fla., CRC.

Menon N.N., 2000. Hydrobiology of Cochin backwater system- A review. Hydrobiologia, 430:149-183.

Mukhopadhyay B. and Dutta A., 2010. A Stream Water Availability Model of Upper Indus Basin based on a Topologic Model and Global Climatic Datasets. Water Resource Management, 24: 4403-4443.

Murari et al., 2001. Future climate change: Implications for Indian summer monsoon and its variability. Current Science, 81.9.

Murthy et al., 2011. Water pollution in India-An economic appraisal. India infrastructure report. New Delhi.

Modeling Report for Total Maximum Daily Load for Skippack Creek, Montgomery County, Pennsylvania, 2005. United States Environmental Protection Agency - Region III. Philadelphia, Pennsylvania.

Muduli S.D., 2006. Physico-chemical characteristic Assesment of Brahmani river Orissa, India. Pollution Research, 25(4): 763-766.

Najafzadeh M. and Azamathulla H.M., 2013. Group method of data handling to predict scour depth around bridge piers. Neural Computer \& Appliations, 23: 2107-2112.

NEERI, 1992. Water quality in Periyar river basin. Report.

Nicholas V.S., 2009. QUAL2K Model Progress Update Jordan River TMDL. Stantec Consultants.

Nipunika R. et al., 2011. Assessment of temporal variation in water quality of some important rivers in middle Gangetic plains, India. Environment Monitoring and Assessment, 174: 401-415.

Nigel W.A., 2004. Climate change and global water resources: SRES emissions and socio-economic 
scenarios. Global Environmental Change, 14: 31-52.

O’Connor D.J. and Dobbins W.E., 1958. Mechanism of reaeration in natural streams. Transactions of the American Society of Civil Engineers, 123: 641666.

Oliveir B. et al., 2011. Application of Qual2Kw model as a tool for water quality management: Certima River as a case study. Environment monitoring and assessment, 184(10): 6197-6210.

Park S.S. and Lee Y.S., 2002. Water quality modeling study of the Nakdong river, Korea. Journal of ecological model, 152: 66-75.

Park S., Na Y. and Uchrin C.G., 1990. Water quality modeling of the lower south branch of the Raritan river, New Jersey. Journal of Academic Science, 35(1): 17-23.

Park S.S. and Lee Y.S., 1996. A multiconstituent moving segment model for the water quality predictions in steep and shallow streams. Ecological Modelling, 89: 121-131.

Paul A.C. and Pillai K.C., 1976. Studies on pollution aspects of Periyar river. Project report.

Pelletier G.J., Chapra S.C. and Tao H., 2006. A framework for modelling water quality in stream and rivers using genetic algorithm for calibration. Journal of Environment Modelling Software, 21: 419-425.

Pelletier G.J. and Chapra S.C., 2005. QUAL2Kw theory and documentation (version 5.1)-A modeling framework for simulating river and stream water quality.

Petrescu V., Sumbasacu G.O. and Sirbu N., 2011. Monitoring and mathematical modelingimportant tools for environmental problems. Journal of Environment Engineering and Management, 10: 1779-1787.

Pimpunchat B. and Sweatman W.L., 2009. A mathematical model for pollution in a river and its remediation by aeration. Journal of Applied Mathematics Letter, 22(3): 304-308.

Potts M.S., 2014. Integration of QUAL2Kw and ArcGIS for Silver Bow Creek, Montana. A non-thesis paper submitted in partial fulfillment of the
Master of Environmental Engineering. Montana Tech of The University of Montana.

Prakash R., 2007. Application of Qual 2Kw for water quality modeling and dissolved oxygen control in the river Bagmati. Environment Monitoring and Assessment, 125: 201-217.

Radwan M., Willems P., Sadek A.El. and Berlamont J., 2003. Modelling of dissolved oxygen and biochemical oxygen demand in river water. Hydraulics laboratory. Belgium.

Rehana S. and Mujumder P.P., 2011. River Water quality response under hypothetical climate change scenarios in Tunga-Bhadra River, India. Hydrological processes. Wiley Online Library, 25(22): 3373-3386.

Schnoor J., 1996. Environmental modeling, fate and transport of pollutants in water, Air, and Soil. Wiley Inter science.

Scott D.W., 1991. Travel time and reaeration characteristics for a reach of the Rio grande, Albuquerque, New Mexico. Water resources Investigations report. US geological survey.

Sieber J. et al., 2005. WEAP, A demand, priority, and preference driven water planning model: Part 1,model characteristics. Water International, 30(4): 487-500.

Shanti, 2001. Studies on the water quality of River Periyar, M.Sc. Thesis. School of environmental sciences. Mahatma Gandhi University. Kottayam.

Sharma D. and Singh R.K., 2009. DO-BOD modeling of river Yamuna for national capital territory, India using STREAM II, a 2D water quality model. Journal of Environment Monitoring and Assessment, 159(1-4): 231-40.

Smith J. and Smith P., 2007. Introduction to Environmental Modeling. Oxford university press. Oxford, UK.

Sokolov S. and Black, 1996. Long term modeling of water quality variables in the Yarra river. Division of marine research, Australia.

Somyody L., 1998. River water quality modelling - III. Future of the art. Water science and Technology, 38(11): 253-60. 
Stringer R.L., Abunska I. and Brigden K., 2003. Pollution from Hindustan insecticide ltd and other factories in Kerala, India: a follow-up study. Green Peace research laboratories. UK.

Stolarska A.Z. and Skrzypski J., 2012. Review of mathematical models of water quality. Ecological Chemical Engineering, 19(2): 197211.

Thomman V.R. and Mueller A.J., 1987. Principles of surface water quality modeling. Harper international edition. Harper and Row, Newyork.

Ugbedor et al., 2012. Determination of reaeration coefficient $\mathrm{K} 2$ for polluted stream as a function of depth, hydraulic radius, temperature and Velocity. Nigerian Journal of Technology, 31(2): 174-180.

UNEP, 1993. Report of the governing council. Seventh session. general assembly official records. Forty eighth session supplement No.25. New York.

UNEP, 2004. United Nation Environment ProgramAnnual Report. New York.

USEPA, 1994. Water quality standards Hand book. EPA's water quality standards (WQS) program. New York. EPA's water quality standards (WQS) program.

Vanrheenen N.T. et al., 2004. Potential Implications of PCM climate change scenarios for Sacramento-
San Joaquin river basin hydrology and water resources. Climate Change, 62: 257-281.

Wilby R., 1995. Modelling the impact of extreme weather on surface water acidity regimes. Proceedings of a boulder symposium-Man's influence on fresh water ecosystems and water use. Department of Geography.

Wilcock R.J., 1988. Study of River Reaeration at Different Flow Rates. Journal of Environmental Engineering, 114(1): 91-105. DOI: 10.1061/ (ASCE) 0733-9372

Zhiqiang D., Lars B. and Vijay P.S., 2006. Parameter estimation for fractional dispersion model for rivers. Environment Fluid Mechanics, 6:451475.

Zhang R. et al., 2012. Selection of optimal river water quality improvement programs using QUAL2K: A case study of Taihu Lake Basin, China. Journal of Science of the Total Environment, 431: 278-285.

Zheng C. and Gordon B., 1995. Applied contaminant transport modeling. Van Nostrand Reinhold, New York.

Zhen-Gang H., 2008. Hydrodynamics and Water QualityModeling Rivers, Lakes and Estuaries. Wiley inter science. John wiley \& sons, New Jersey. 